\title{
Transparent exopolymer particles (TEP) link phytoplankton and bacterial production in the Gulf of Aqaba
}

\author{
Edo Bar-Zeev ${ }^{1, *}$, Ilana Berman-Frank ${ }^{1}$, Noga Stambler ${ }^{1,2}$, \\ Evaristo Vázquez Domínguez ${ }^{3}$, Tamar Zohary ${ }^{4}$, Elisa Capuzzo ${ }^{5}$, Efrat Meeder ${ }^{6,7}$, \\ David J. Suggett ${ }^{8}$, David Iluz ${ }^{1,2}$, Gal Dishon ${ }^{1}$, Tom Berman ${ }^{4}$ \\ ${ }^{1}$ The Mina \& Everard Goodman Faculty of Life Sciences, Bar Ilan University, Ramat Gan 52900, Israel \\ ${ }^{2}$ Department of Geography and Environment, Bar-Ilan University, Ramat-Gan 52900, Israel \\ ${ }^{3}$ CSIC, Institut de Ciències del Mar, Passeig Marítim de la Barceloneta, 39-43, 08003 Barcelona, Spain \\ ${ }^{4}$ Israel Oceanographic and Limnological Research, The Yigal Allon Kinneret Limnological Laboratory, Tiberias 14102, Israel \\ ${ }^{5}$ School of Life Sciences, Napier University, Edinburgh EH10 5DT, UK \\ ${ }^{6}$ The Interuniversity Institute for Marine Sciences Coral Beach, POB 469, 88103 Eilat, Israel \\ ${ }^{7}$ Institute of Earth Sciences, The Hebrew University Edmond J. Safra Campus, Jerusalem 91904, Israel \\ ${ }^{8}$ Department of Biological Sciences, University of Essex, Colchester CO4 3SQ, UK
}

\begin{abstract}
Variations in transparent exopolymer particles (TEP), bacterial biomass production (BP) and primary productivity (PP) were followed over $52 \mathrm{~h}$ at a deep water station in the Gulf of Aqaba (Eilat, Israel) during the spring, in April 2008. About $20 \mathrm{~h}$ after the start of the study, there was a short $(\sim 15 \mathrm{~h})$ but intense storm event that probably caused a nutrient pulse and, subsequently, a brief outgrowth of diatoms in the euphotic layer. Concentrations of TEP and BP ranged from 23 to $228 \mu \mathrm{g}$ gum xanthan equivalents $\mathrm{l}^{-1}$ and from 0.2 to $0.6 \mu \mathrm{g} \mathrm{Cl}^{-1} \mathrm{~h}^{-1}$, respectively. Concentrations of TEP and BP were measured in unfiltered and in GF/C $(1.2 \mu \mathrm{m})$-prefiltered samples. Most of the TEP $(59 \pm 21 \%$ of total TEP, mean $\pm \mathrm{SD}$ ) were in the smaller (GF/C-filtered) size fraction $(0.4-1.2 \mu \mathrm{m})$; however, after the crash of the diatom bloom, the majority of TEP were in the $>1.2 \mu \mathrm{m}$ size fraction. In the GF/Cfiltered fraction, BP averaged $59 \pm 12 \%$ and $93 \pm 5 \%$ of total BP in the upper water column and from $300 \mathrm{~m}$, respectively. Significant correlations were observed between TEP and BP, suggesting that active heterotrophic bacteria may have been associated with these particles. During the $3 \mathrm{~d}$ of our study, PP and BP in the euphotic zone averaged 480 and $225 \mathrm{mg} \mathrm{C} \mathrm{m}^{-2} \mathrm{~d}^{-1}$, respectively, suggesting that about half or more of the primary produced carbon was metabolized by heterotrophic bacteria in the upper water column. Coincident with strong mixing caused by the storm, TEP concentrations decreased in the surface water and increased at depth. We suggest that TEP acted to link carbon flux between the primary producers and heterotrophic bacteria, and that the downward movement of TEP from the upper water layers may be an important process in transferring organic carbon to deeper waters of the Gulf of Aquaba. Sinking TEP could provide not only organic carbon substrates for associated bacteria but also form 'hot spots' of elevated microbial metabolism and nutrient cycling throughout the water column.
\end{abstract}

KEY WORDS: Transparent exopolymer particles $\cdot$ TEP $\cdot$ Bacterial productivity $\cdot$ Primary productivity · Carbon cycling $\cdot$ Size fractionation $\cdot$ Gulf of Aqaba

\section{INTRODUCTION}

Since first described by Alldredge et al. (1993), the ubiquity and important role of transparent exopolymer particles (TEP) in aquatic environments have been extensively documented (Passow 2002a). TEP are microscopic, transparent organic particles that consist mainly of acid polysaccharides and which can be 
detected by staining with Alcian Blue. TEP range in size from 0.4 to $\sim 200 \mu \mathrm{m}$ and appear in many forms: amorphous blobs, clouds, sheets, filaments or clumps. TEP are negatively charged, often enriched in fucose and rhamnose (Zhou et al. 1998, Passow 2002b, Mari et al. 2004), and may adsorb other organic molecules and trace metals. TEP can serve as 'hot spots' of intense microbial and chemical activity within the water mass (Azam \& Long 2001) because of their high nutrient content and sticky characteristics (Passow \& Alldredge 1994, Mari \& Kiørboe 1996). Because of the gel-like structure and large surface area of TEP, it has been estimated that, in some marine waters, between 50 to $90 \%$ of the total bacterial community is associated with these particles (Passow \& Alldredge 1994, Schuster \& Herndl 1995, Mari \& Kiørboe 1996, Worm \& Sondergaard 1998).

TEP can be formed via either abiotic or biotic processes. In some aquatic environments, TEP form abiotically from colloidal, dissolved organic matter (DOM) by coagulation and gelation (Chin et al. 1998, Mari 1999, Passow 2000) or by adsorption to bubbles (Mopper et al. 1992). The formation of TEP is stimulated by turbulence (Kepkay 2000). Considerable amounts of TEP are also produced by sheer forces acting to remove parts of the gelatinous envelopes surrounding diatoms and other algae (Passow et al. 1994, Berman \& Viner-Mozzini 2001) and from bacterial mucus (Stoderegger \& Herndl 1999). Direct proliferation of mucus and, subsequently, TEP has been observed in senescent or nutrient-stressed algae and cyanobacteria (Grossart et al. 1997, Berman-Frank et al. 2007). Probably the most abundant marine phytoplankton source of TEP are diatoms, given their size and high production of extrapolymeric substances (EPS) (Thornton 2002). Laboratory and field experiments have confirmed that TEP secretions contribute to the stickiness of diatom cell surfaces (Smetacek 1985, Grossart \& Ploug 2001, Passow et al. 2003) and play an important role in their aggregation following blooms (Alldredge et al. 1993, Passow \& Alldredge 1994, Engel 2000). Logan \& Alldredge (1989) observed that newly formed diatom aggregates could sink with velocities reaching up to $200 \mathrm{~m} \mathrm{~d}^{-1}$. Field observations have further shown a close correlation between phytoplankton primary production at the surface and TEP flux to deeper water (Mari \& Burd 1998), and this has been invoked as a major transfer pathway for particulate organic carbon (POC) from the photic zone to deep water in marine systems (Engel et al. 2004, Arrigo 2007).

This is the first study of TEP in the oligotrophic Gulf of Aqaba (Eilat). The northern Gulf of Aqaba is characterized physically not only by intense summer stratification but also by extremely deep winter mixing down to $>850 \mathrm{~m}$ depth (Genin et al. 1995). Concentrations of available $\mathrm{N}$ and $\mathrm{P}$ in the euphotic zone are generally low throughout the year, despite winter mixing from January to March (Genin et al. 1995, Al-Qutob et al. 2002, Labiosa \& Arrigo 2003). Chlorophyll a (chl a) concentrations in the euphotic water column average

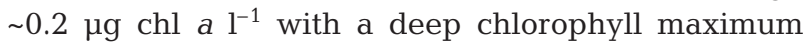
(DCM) forming during spring and summer months (Stambler 2006). Primary productivity is low throughout the year with a winter maximum of $3.4 \mathrm{mg} \mathrm{C} \mathrm{m}^{-3}$ $\mathrm{d}^{-1}$ in near-surface waters (Iluz 1997).

Our data were collected in late winter/early spring, when diatoms such as Chaetoceros sp. and dinoflagellates often dominate the near-surface layers while picophytoplankton, mainly Synechococcus, populate the deeper water (Lindell \& Post 1995, Iluz 1997, Stambler 2006).

We document the dynamics of the spatial and temporal distribution of 2 size-fractions of TEP $(0.4-1.2 \mu \mathrm{m}$ and $>1.2 \mu \mathrm{m})$, and the corresponding changes of bacterial biomass carbon production (BP) and primary productivity (PP), over a $52 \mathrm{~h}$ period. Our results suggest that TEP play a critical role in the transport of organic carbon from the surface to deeper waters and in linking carbon flux between photosynthetic phytoplankton and heterotrophic bacteria in the Gulf of Aqaba. Note: throughout this paper, we use the term 'bacteria' to denote both Bacteria and Archaea.

\section{MATERIALS AND METHODS}

Sampling strategies. A series of CTD casts $(0$ to $300 \mathrm{~m}$ ) were made during early April 2008 in the northern Gulf of Aqaba at Station A1 $\left(29.28^{\circ} \mathrm{N}, 34.55^{\circ} \mathrm{E}\right.$; bottom depth $650 \mathrm{~m}$ ). Water samples for TEP and BP were collected at 3 depths (5 m, DCM [between 30 and $40 \mathrm{~m}$ ] and $300 \mathrm{~m}$ ) using 81 Niskin bottles mounted on a Rosette equipped with a CTD. The sampling times for the casts were $18: 40 \mathrm{~h}$ on 1 April; $03: 00 \mathrm{~h}, 10: 30 \mathrm{~h}$ and 17:30 h on 2 April; and 15:45 h on 3 April. One-litre portions of these samples were size-fractionated by filtration through $\mathrm{GF} / \mathrm{C}(\sim 1.2 \mu \mathrm{m})$ filters.

Phytoplankton was sampled from 2 depths $(5 \mathrm{~m}$ and DCM) between 12:00 h on 1 April and 20:00 h on 3 April. Our study began at 12:00 h on 1 April; therefore, we refer to this time point as time zero $(0 \mathrm{~h})$ throughout.

Phytoplankton abundance. Phytoplankton population composition and abundance were determined in samples fixed with $100 \mu \mathrm{l}$ of $26 \%$ glutaraldehyde using an inverted microscope and following the Utermöhl (1958) method. The carbon biomass of the microphytoplankton population was calculated according to Edler (1979) and Menden-Deuer \& Lessard (2000). 
Picophytoplankton $(<2 \mu \mathrm{m})$ abundance was measured by flow cytometry using cell side-scatter as a proxy of cell volume; forward scatter as a proxy of cell size; and orange and red fluorescence of phycoerythrin and of chl a (585 and $630 \mathrm{~nm}$, respectively). Samples $(1.8 \mathrm{ml})$ were fixed immediately at room temperature for 20 min with $23 \mu$ of $25 \%$ glutaraldehyde (Sigma G5882), frozen in liquid nitrogen and kept at $-80^{\circ} \mathrm{C}$ until analysis. For analysis, samples were quickly thawed at $37^{\circ} \mathrm{C}$ and counted in a FACScalibur (Becton \& Dickinson) flow cytometer. A minimum of 10000 cells was counted; $0.93 \mu \mathrm{m}$ beads (PolysciencesTM) served as standards. Picophytoplankton carbon biomass was calculated as $175 \mathrm{fg} \mathrm{C}$ cell $^{-1}$ for Synechococcus (the majority of cyanobacterial cells), as $53 \mathrm{fg} \mathrm{C}^{\mathrm{C}} \mathrm{cell}^{-1}$ for Prochlorococcus, and as $2100 \mathrm{fg} \mathrm{C} \mathrm{cell}{ }^{-1}$.

Primary productivity (PP). The underwater light field was measured from the surface to $100 \mathrm{~m}$ water depth with a Biospherical PRR-800 spectroradiometer. PP was estimated from the upwelling radiance of chlorophyll natural fluorescence as:

$$
F_{\mathrm{c}}=F_{\mathrm{f}}\left(k_{\mathrm{cf}} \phi_{\text {rmax }}\right) /\left(k_{\mathrm{cf}}+E_{0}\right)
$$

where $F_{\mathrm{C}}$ is the rate of photosynthetic carbon fixation, $\left(F_{\mathrm{f}}\right)$ is the fluorescence at $683 \mathrm{~nm}$ derived from the upwelling radiance of chlorophyll natural fluorescence per volume, $\left(E_{0}\right)$ is the incident photosynthetically available irradiance per $\mathrm{m}^{2}, \phi_{r \max }$ is the ratio of the quantum yields of photosynthesis to fluorescence, and $\left(k_{\mathrm{cf}}\right)$ is the irradiance at which this ratio is $1 / 2$ of the maximum (for details of this approach see Bidigare et al. 1987, 1989, Keifer et al. 1989 and Chamberlin et al. 1990). A close correlation $\left(\mathrm{r}^{2}=0.823, \mathrm{p}<0.0001, \mathrm{n}=24\right)$ was found between PP estimated using this method and using ${ }^{14} \mathrm{C}$ productivity measurements made at the same time in these waters (Iluz et al. 2009, this Special Issue).

Bacterial production (BP). BP was determined using the leucine incorporation method (Kirchman et al. 1985, Simon \& Azam 1989) as modified by Smith \& Azam (1993). All samples were run in triplicate with zero time controls. Leucine incorporation was converted to BP using a factor of $3.1 \mathrm{~kg} \mathrm{C} \mathrm{mol}^{-1}$ with an isotope dilution factor of 2.0 (Simon \& Azam 1989). BP (and TEP, see below) was measured in samples from both unfiltered and GF/C-filtered water.

Determination of TEP. The concentrations of TEP (as $\mu \mathrm{g}$ gum xanthan [GX] equivalents $\mathrm{l}^{-1}$ ) in bulk water samples filtered onto $0.4 \mu \mathrm{m}$ polycarbonate filters and in samples subsequently filtered through $1.2 \mu \mathrm{m}$ GF/C filters were measured using the technique of Passow \& Alldredge (1995). The 2 resulting fractions are termed 'total TEP' (>0.4 $\mu \mathrm{m})$ and 'small TEP' [S-TEP] (0.4-1.2 $\mu \mathrm{m})$. 'Large TEP' [L-TEP] (>1.2 $\mu \mathrm{m})$ was determined by subtracting the concentration of S-TEP from total TEP.

\section{RESULTS}

\section{Phytoplankton and nutrients}

At the beginning of our study (1 April, 12:00 h), the Gulf was calm with extremely low winds ( $<5 \mathrm{kn}$ ) (Fig. 1). In near-surface waters (0 to $40 \mathrm{~m}$ ), concentrations of dissolved inorganic nitrogen (DIN; nitrite and nitrate) ranged between 0.01 to $0.02 \mu \mathrm{M} N$. In terms of phytoplankton biomass carbon, picophytoplankton $(<2 \mu \mathrm{m})$ were predominant $\left(50 \mu \mathrm{g} \mathrm{C} \mathrm{l}^{-1}\right)$ over the microphytoplankton $\left(0.5 \mu \mathrm{g} \mathrm{C} \mathrm{l}^{-1}\right)$. Diatoms, mainly Chaetoceros $\mathrm{cf}$. compressus and Chaetoceros curvisetus, were the main component (76 to $97 \%$ ) of the microphytoplankton. About $20 \mathrm{~h}$ after the start of our study, a northerly storm with winds reaching a maximum of 20 to $25 \mathrm{kn}$ began and lasted for $\sim 20 \mathrm{~h}$. DIN in near-surface waters increased abruptly, reaching concentrations of 0.08 to $0.1 \mu \mathrm{M} N$, presumably as a result of storm-induced mixing and transport. A steady increase in diatom biomass was recorded, reaching a peak of $20.1 \mu \mathrm{g} \mathrm{Cl}^{-1}$ at $41 \mathrm{~h}$. In contrast to the diatoms, picophytoplankton dropped to $22 \mu \mathrm{g} \mathrm{C} \mathrm{l}^{-1}$ towards the end of the storm. DIN levels subsequently decreased to 0.01 to $0.03 \mu \mathrm{M} \mathrm{N}$, and, concomitantly, a second shift between the phytoplankton communities was observed with diatom biomass decreasing to $5.4 \mathrm{\mu g} \mathrm{Cl}^{-1}$ while picophytoplankton again became dominant with values reaching $40 \mu \mathrm{g} \mathrm{Cl}^{-1}$.

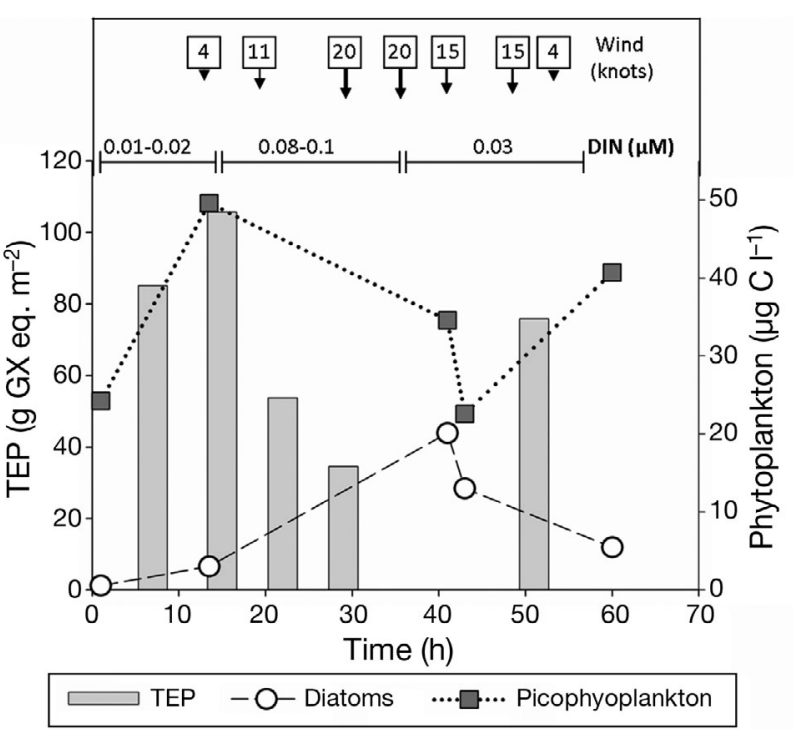

Fig. 1. Temporal changes in biological, physical and chemical characteristics at a deep water station, northwestern Gulf of Aqaba. Phytoplankton (diatoms and picophytoplankton) were counted in samples from $5 \mathrm{~m}$ water depth. Values for transparent exopolymer particles (TEP) are integrated from the surface to $300 \mathrm{~m}$ water depth. Dissolved inorganic nitrogen (DIN; nitrite and nitrate) was measured daily near the surface $(0$ to $30 \mathrm{~m})$. Wind data were recorded at the Interuniversity Institute, Eilat 


\section{Primary productivity}

Fig. 2 shows the changes in PP in the upper water layer (surface to DCM) over the course of our study as estimated from upwelling chlorophyll natural fluorescence obtained with a spectroradiometer and calibrated against ${ }^{14} \mathrm{C}$ (Kiefer et al. 1989, Chamberlin et al. 1990, Chamberlin \& Marra 1992). The overall pattern of PP reflects the shifts observed in phytoplankton population composition, DIN concentrations (Fig. 1) and chl a (Fig. 2) during this time. For the $3 \mathrm{~d}$ of this study, daily areal PP from surface to the DCM was $437 \mathrm{mg} \mathrm{C}$ $\mathrm{m}^{-2} \mathrm{~d}^{-1}$ (1 April), $502 \mathrm{mg} \mathrm{C} \mathrm{m}^{-2} \mathrm{~d}^{-1}$ (2 April) and $498 \mathrm{mg}$ $\mathrm{C} \mathrm{m}^{-2} \mathrm{~d}^{-1}$ (3 April).

\section{TEP}

Concentrations of TEP at all depths measured ranged from 23 to $228 \mu \mathrm{g}$ GX equivalents $\mathrm{l}^{-1}$. Areal concentrations of TEP, estimated by integration between $0 \mathrm{~m}$ to the DCM, varied about 3 fold during the course of the study. Initially, at 7 and $15 \mathrm{~h}$, areal TEP concentrations were 6657 and $6740 \mathrm{mg}$ GX equivalents $\mathrm{m}^{-2}$, respectively. After this time, they dropped to $3634 \mathrm{mg}$ GX equivalents $\mathrm{m}^{-2}$ at $22 \mathrm{~h}$ and to $3207 \mathrm{mg}$ GX equivalents $\mathrm{m}^{-2}$ at $29 \mathrm{~h}$, coincident with the rise and peak of the diatom bloom. Subsequently, by the final sampling time $(52 \mathrm{~h})$, areal TEP concentrations had increased again to $4149 \mathrm{mg}$ GX equivalents $\mathrm{m}^{-2}$. The variations in areal TEP concentrations in the upper water column ( $0 \mathrm{~m}$ to DCM) over time are shown in Fig. 2.

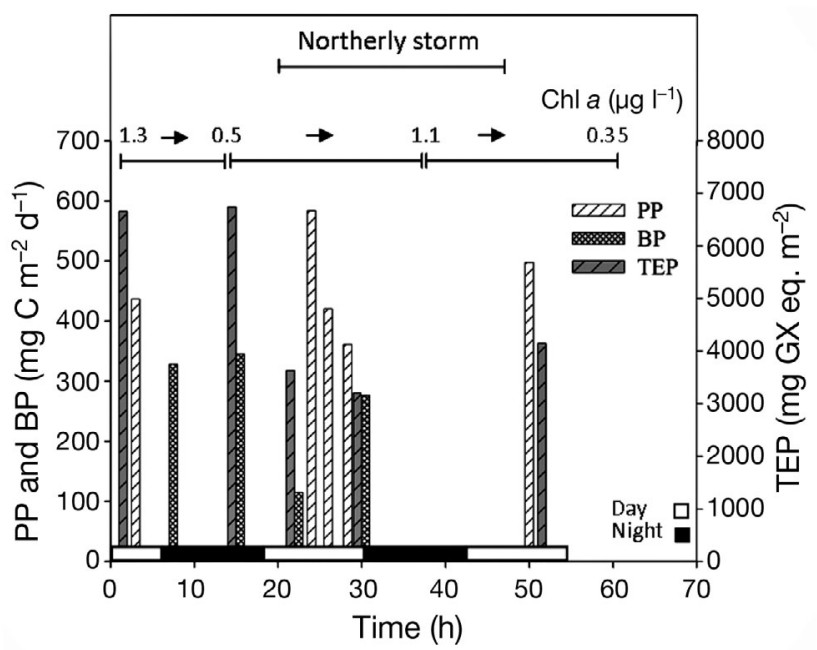

Fig. 2. Northwestern Gulf of Aqaba: temporal changes in primary production (PP), bacterial production (BP) and transparent exopolymer particles (TEP) in the euphotic water column (surface to deep chlorophyll maximum). Chlorophyll a (chl a) values were measured at the DCM
During the study, there were marked changes in the distribution of TEP concentrations in the water column down to $300 \mathrm{~m}$ (Fig. 3A). For the first $15 \mathrm{~h}$, we observed relatively high levels of TEP in the near-surface and DCM samples (222 to $228 \mu \mathrm{g}$ GX equivalents $\mathrm{l}^{-1}$ ), and lower TEP concentrations at $300 \mathrm{~m}$ (163 to $137 \mu \mathrm{g} \mathrm{GX}$ equivalents $\mathrm{l}^{-1}$ ). Then, with the onset and progression of the northerly storm (from 20 to $40 \mathrm{~h}$ ), TEP concentrations, especially those at $5 \mathrm{~m}$ and the DCM, fell sharply (130 and $106 \mu \mathrm{g}$ GX equivalents $\mathrm{l}^{-1}$, respectively). By $52 \mathrm{~h}$, the depth distribution pattern of TEP was reversed, with concentrations at the near-surface and DCM being lower than those in the $300 \mathrm{~m}$ sample (110, 166 and $209 \mu \mathrm{g}$ GX equivalents $\mathrm{l}^{-1}$, respectively).

For all samples, S-TEP ranged from 21 to $85 \%$ of total TEP, with a mean of $59 \pm 21 \%$. S-TEP was $56 \pm$ $22 \%$ and $66 \pm 18 \%$ of total TEP in the upper water layer and at $300 \mathrm{~m}$, respectively. Prior to the diatom bloom, when picophytoplankton dominated in the water column, S-TEP contributed 46 to $85 \%$ of total

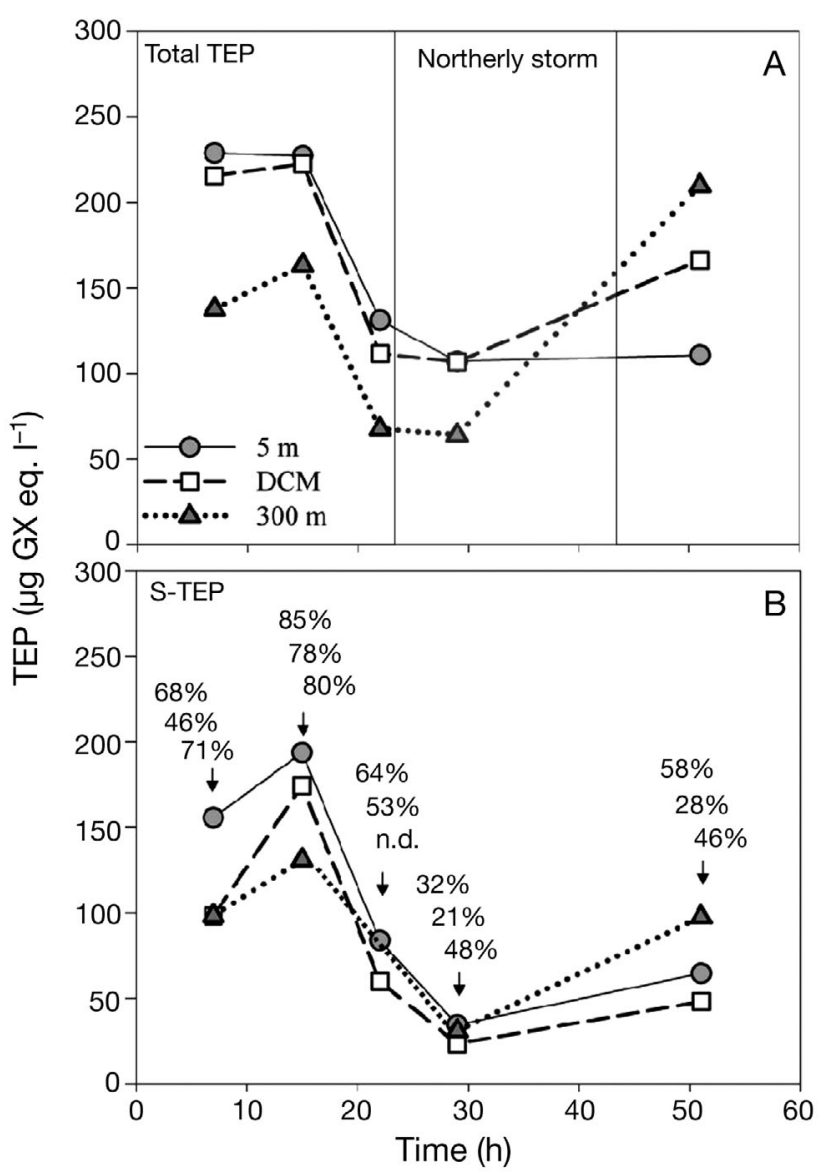

Fig. 3. Northwestern Gulf of Aqaba: temporal changes in sizefractionated TEP measured at 3 depths (at $5 \mathrm{~m}$, the deep chlorophyll maximum, and $300 \mathrm{~m}$ ). (A) Total TEP. (B) Small TEP (S-TEP), 0.4-1.2 $\mu \mathrm{m}$ size fraction. The numbers in (B) show the percentages of S-TEP relative to total TEP at each of the sampled depths (top to bottom). n.d.: not determined 
TEP, with the lowest percentage observed at the DCM (Fig. 3B). During the diatom bloom (15 to 29 h), S-TEP steadily declined relative to L-TEP, from $\sim 80 \%$ to $22-32 \%$ in the upper water layers. By $52 \mathrm{~h}$, following the crash of the diatom bloom, S-TEP (58\%) had increased relative to L-TEP at the surface but not at the DCM $(28 \%)$. At $300 \mathrm{~m}, \mathrm{~S}-\mathrm{TEP}$ was $71 \%$ of total TEP initially but dropped to $46 \%$ by $52 \mathrm{~h}$.

\section{Bacterial productivity}

BP in unfiltered water samples in the upper water column (5 $\mathrm{m}$ and DCM) varied only 3 -fold (from 0.2 to $0.6 \mu \mathrm{g} \mathrm{C}^{-1} \mathrm{~h}^{-1}$ ) during the course of our observations. The pattern of BP showed initially higher values that dropped after $15 \mathrm{~h}$ and eventually increased again after $20 \mathrm{~h}$ (Fig. 2). From the surface to the DCM, BP

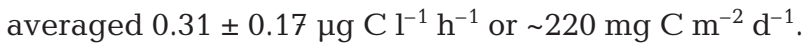
The levels of BP were about an order of magnitude lower at $300 \mathrm{~m}$ with $0.032 \pm 0.016 \mu \mathrm{g} \mathrm{Cl}^{-1} \mathrm{~h}^{-1}$ and ranging from 0.002 to $0.046 \mu \mathrm{C}^{-1} \mathrm{~h}^{-1}$.

In the upper water column (5 $\mathrm{m}$ and DCM), BP in the $<1.2 \mu \mathrm{m}$ fraction averaged $59 \pm 12 \%$ of total BP. In comparison, almost all BP (93 $\pm 5 \%)$ was in the $<1.2 \mu \mathrm{m}$ fraction at $300 \mathrm{~m}$.

We observed a significant positive correlation $\left(\mathrm{r}^{2}=\right.$ $0.508, \mathrm{p}=0.001, \mathrm{n}=23$ ) between BP and TEP concentrations measured in all (unfiltered and GF/C-filtered) samples (Fig. 4A). Additionally, BP in GF/C-filtered samples was significantly correlated with S-TEP from all depths $\left(r^{2}=0.49, p=0.025, n=10\right.$, Fig. 4B) and from upper waters $\left(\mathrm{r}^{2}=0.53, \mathrm{p}=0.04, \mathrm{n}=8\right.$, data not shown). No significant correlations resulted from regressing total TEP or BP in the $>1.2 \mu \mathrm{m}$ fraction against L-TEP. Significant positive correlations were also determined

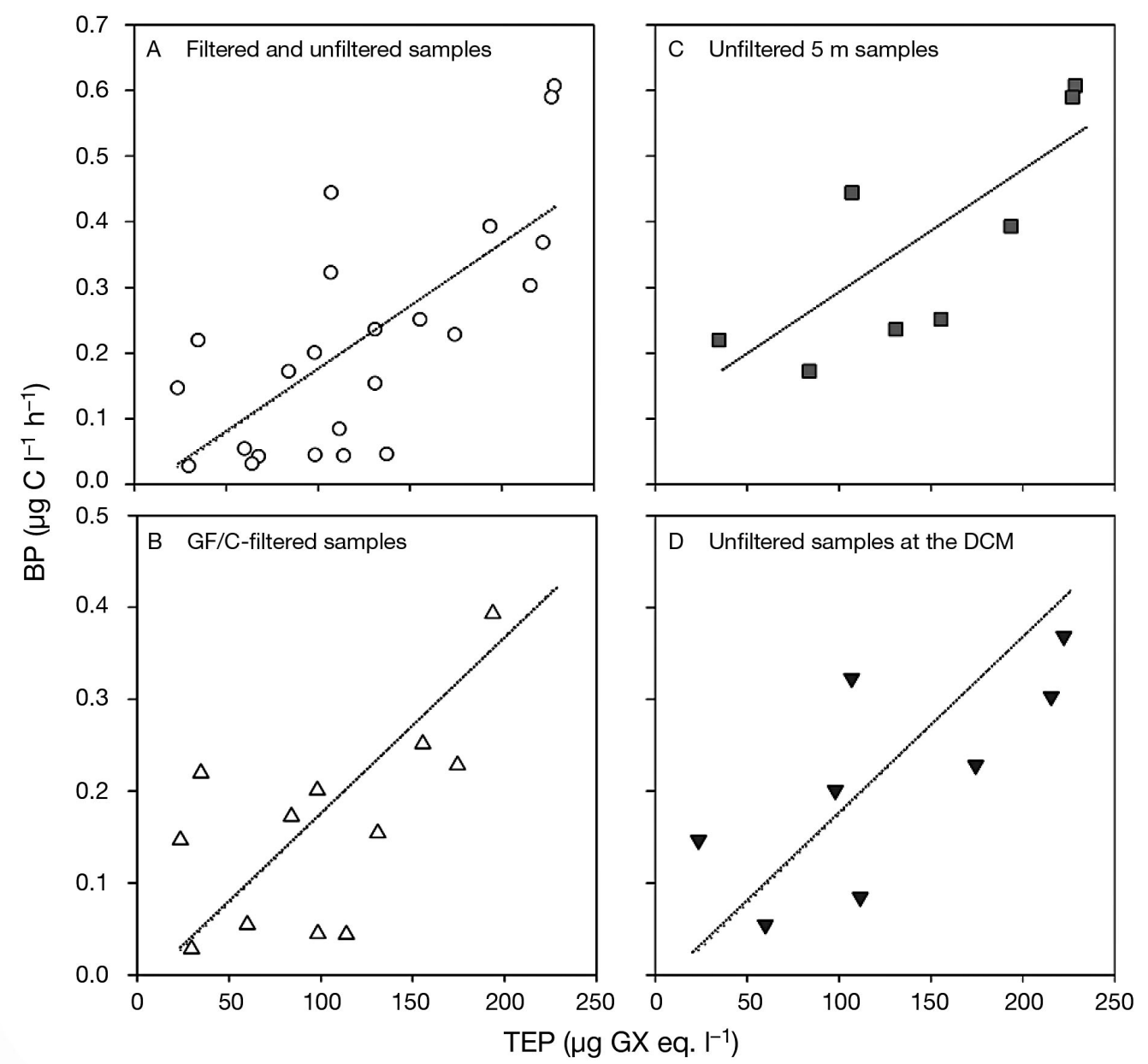

Fig. 4. Northwestern Gulf of Aqaba: linear regression of bacterial production (BP, $\left.\mu \mathrm{g} \mathrm{C}^{-1} \mathrm{~h}^{-1}\right)$ against transparent exopolymer particles (TEP, $\mu$ g GX equivalents $\mathrm{l}^{-1}$ ). (A) GF/C-filtered and unfiltered samples, BP =0.0019 (TEP) $-0.0186\left(\mathrm{r}^{2}=0.508, \mathrm{p}=0.001\right.$, $\mathrm{n}=23)$. (B) $\mathrm{GF} / \mathrm{C}$-filtered fraction, $\mathrm{BP}=0.0013(\mathrm{~S}-\mathrm{TEP})+0.0534\left(\mathrm{r}^{2}=0.486, \mathrm{p}=0.025, \mathrm{n}=10\right)$. (C) Unfiltered samples from $5 \mathrm{~m}$ water depth: $\mathrm{BP}=0.0019(\mathrm{TEP})+0.0828\left(\mathrm{r}^{2}=0.62, \mathrm{p}=0.02, \mathrm{n}=8\right)$. (D) Data from unfiltered samples at the DCM: $\mathrm{BP}=0.0011$ $(\mathrm{TEP})+0.0689\left(\mathrm{r}^{2}=0.52, \mathrm{p}=0.04, \mathrm{n}=8\right)$ 
between BP and TEP (unfiltered and filtered samples) at $5 \mathrm{~m}\left(\mathrm{r}^{2}=0.62, \mathrm{p}=0.02, \mathrm{n}=8\right)$ (Fig. $\left.4 \mathrm{C}\right)$ and at the $\operatorname{DCM}\left(\mathrm{r}^{2}=0.52, \mathrm{p}=0.04, \mathrm{n}=8\right)$ (Fig. $\left.4 \mathrm{D}\right)$, but no significant correlation was found for samples from $300 \mathrm{~m}$ water depth.

\section{DISCUSSION}

\section{TEP dynamics}

The Gulf of Aqaba is considered to be oligotrophic with annual fluctuations in phytoplankton biomass and primary productivity (Lindell \& Post 1995). In late winter/early spring, extremely deep mixing occurs, bringing nutrients to the surface (Genin et al. 1995). The phytoplankton community undergoes pronounced seasonal changes, with picophytoplankton (Synechococcus and Prochlorococcus) dominating (95\%) during the spring-summer stratification and short-lived blooms of microphytoplankton (diatoms and dinoflagellates) during winter mixing (Reiss \& Hottinger 1984, Lindell \& Post 1995).

In the course of our short-term survey, we observed marked fluctuations both in phytoplankton abundance and population composition (Fig. 1). These changes were almost certainly caused by a brief but intense storm event that brought about strong mixing of the upper water column with upwelling at the north and east and downwelling at the western side of the Gulf (Genin et al. 1995). Between 15 to $40 \mathrm{~h}$, we recorded a sharp rise in diatoms, concomitant with a drop in picophytoplankton. Chl a levels and PP also peaked at this time (Fig. 2). A further $20 \mathrm{~h}$ later, diatom abundance had decreased while picophytoplankton increased again. Such transient blooms are common in the Gulf during the winter-spring transition (Al-Najjar et al. 2007). The observed changes in the phytoplankton community may have occurred in response to similar fluctuations in DIN concentrations (Fig. 1), and the abrupt crash of the diatom bloom may have reflected changes in their physiological state from nutrient adequacy to stress.

Experimental studies in microcosms (Allgaier et al. 2008) and field data (Berman-Frank et al. 2007) support the idea that phytoplankton physiological state is coupled to secretion of TEP. In diatom cultures, nutrient limitation (especially N) and/or senescence have been been related to increased TEP release (Hong et al. 1997, Corzo et al. 2000, Engel et al. 2002). In various ocean environments, high TEP concentrations have been observed towards the final phase of diatom blooms (Passow \& Alldredge 1994, Mari \& Burd 1998).

The changes in the relative abundance of S-TEP to L-TEP observed during our study (Fig. 3) may also have been related to the fluctuations in phytoplankton populations. Initially (until $23 \mathrm{~h}$ ), corresponding to the period of picoplankton domination, S-TEP at the nearsurface comprised the majority of total TEP. Towards the peak of the diatoms (at $29 \mathrm{~h}$ ), L-TEP became predominant in the upper water layers ( 70 and $80 \%$ at $5 \mathrm{~m}$ and at the DCM, respectively), but only for a short time (Fig. 3B). Subsequently, at the next sampling time (52 h), L-TEP, which may have been rapidly sinking, had decreased to $\sim 40 \%$ at $5 \mathrm{~m}$ although still comprising $\sim 70 \%$ of total TEP at the DCM (Fig. 3B).

In view of the above, we suggest that the observed temporal succession of TEP concentrations and sizedistribution in the euphotic water column (Figs. 1 to 3) was related to the changes in diatom abundance. During the exponential growth phase, when DIN concentrations and PP were high, leading to the peak of diatoms, the algal cells would not be expected to release much TEP and, indeed, concentrations of these particles declined. Following the diatom bloom, when PP was still relatively high but DIN decreased sharply, there may have been uncoupling between PP and cell growth, leading to TEP release (Berman-Frank et al. 2007) and giving rise to the increased level of areal TEP in the water column that was observed at $52 \mathrm{~h}$ (Fig. 2). TEP generated in the upper water layer would tend to sink rapidly as a result of downwelling currents generated by the strong northerly storm event. Northerly winds in late winter/spring have been shown to cause strong downwelling, reaching depths of around $300 \mathrm{~m}$ in the western Gulf of Aqaba (Labiosa \& Arrigo 2003). Such a process could explain our data showing increased concentrations of TEP at $300 \mathrm{~m}$ and also, to some extent, at the DCM after $52 \mathrm{~h}$ (Fig. 3).

Based on our observations, we suggest that flux of TEP from upper water layers could be an important process in organic carbon transfer to deep waters of the Gulf. This follows from previous indications that polysaccharide aggregates such as TEP may act to transport POC from the upper water column to deeper layers (Engel et al. 2004, Arrigo 2007). Sinking TEP could provide not only organic carbon substrates for associated bacteria, but could also form 'hot spots' of elevated microbial metabolism and nutrient cycling throughout the water column (Azam 1998, Thornton 2002).

\section{Bacterial productivity and TEP}

As yet, there have been only a few measurements of BP in the Gulf of Aqaba. Grossart \& Simon (2002) reported BP ranging from 0.001 to $0.057 \mu \mathrm{g} \mathrm{Cl}^{-1} \mathrm{~h}^{-1}$ with an average areal BP of $\sim 65 \mathrm{mg} \mathrm{C} \mathrm{m}^{-2} \mathrm{~d}^{-1}$ for samples down to $150 \mathrm{~m}$ water depth taken in the Gulf in 1999. These values are considerably lower than our 
measurements for the upper water layers and may represent the more oligotrophic situation that is typical for the Gulf waters throughout most of the year. Our samples were taken when phytoplankton biomass was relatively high with chl a concentrations ranging from

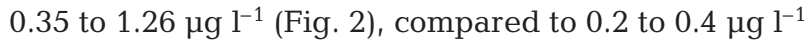
during other seasons. Note that our measurements of $\mathrm{BP}$ in the upper water layers were about 10 -fold higher than at $300 \mathrm{~m}$.

The results from size fractionation of $\mathrm{BP}$ also indicate a qualitative difference between heterotrophic bacterial activity in the euphotic zone and in the deeper water. At $300 \mathrm{~m}, \sim 90 \%$ of total BP was measured in the GF/C-filtered fraction; presumably due to either 'freeliving' bacteria or bacteria associated with $<1.2 \mu \mathrm{m}$ particles, perhaps S-TEP. In the upper water layers, a much greater proportion $(\sim 40 \%)$ of the total BP derived from the $>1.2 \mu \mathrm{m}$ fraction.

The significant correlations observed between BP and TEP measured in both unfractionated and GF/Cfiltered samples (Fig. 4) indicate that much of the heterotrophic bacterial activity may have been associated with these particles. Our finding of a close correlation between BP and TEP concentrations in the upper water layers does not necessarily imply that the bacteria were firmly attached to the TEP. However, it does suggest that BP was located within, on, or associated with these particles, as depicted by Azam (1998). To the best of our knowledge, no such direct relationship has been previously reported from field studies, although Allgaier et al. (2008) also noted a positive relationship between TEP and BP in a macrocosm study. The presence of bacteria on and within TEP has been frequently reported (e.g. Passow \& Alldredge 1994, Mari \& Kiorboe 1996, Carrias et al. 2002), and these particles have been shown to serve as 'hot spots' of microbial activity (Passow 2002b). Several studies have shown that the specific metabolic activity of bacterial cells associated with particles is generally greater than that of 'free-living' bacteria (Simon et al. 1990, Thornton 2002).

A comparison of the estimates for the average areal values from the surface to the DCM of PP ( 480 mg C $\left.\mathrm{m}^{-2} \mathrm{~d}^{-1}\right)$ and of BP $\left(\sim 225 \mathrm{mg} \mathrm{C} \mathrm{m}^{-2} \mathrm{~d}^{-1}\right)$ from 1 to 3 April during our study (Fig. 2) suggests that about half or more of the carbon from PP may have been metabolized by heterotrophic bacteria in the upper water column during this period of unusually high PP for this locality. This BP:PP ratio lies at the upper end of the 0.2 to 0.4 range reported by Cole et al. (1988) in their extensive cross-system review of bacterial production. Subsequently, however, higher BP:PP ratios (0.5 to 0.8) have been reported from the euphotic zones of other marine systems (Herndl et al. 2008, VázquezDomínguez et al. 2008). Clearly, in order to have a more comprehensive understanding of the carbon cycling in the Gulf of Aqaba, we need comparative data on the levels of BP and PP during other seasons when more typical, extremely oligotrophic conditions occur.

\section{Summary}

Taken together, our short-term observations of the temporal pattern of phytoplankton population composition and abundance, TEP and BP in the Northern Gulf of Aqaba suggest the following possible scenario. After an initially calm period, an intense but brief northerly storm event caused a nutrient pulse that stimulated PP and a short-lived bloom of diatoms in the euphotic water column. The storm generated strong downwelling in the western Gulf that led to a shift in the depth distribution of TEP so that, by our final sampling time at $52 \mathrm{~h}$, TEP concentrations were greatest at $300 \mathrm{~m}$. Thus, near-surface TEP, some of which may have derived from the transient bloom of diatoms (Thornton 2002) as well as from other phytoplanktonic primary producers, could have served to transport organic carbon to deeper waters (Arrigo 2007). BP in the upper water layers was shown to be closely correlated with TEP, suggesting that these particles may serve to link carbon flux from primary producers to heterotrophic bacteria either directly, by supplying available organic substrates, or indirectly, by providing foci of enhanced microbial activity and nutrient cycling.

Acknowledgements. We are grateful to 3 reviewers whose comments and critique enabled us to significantly improve this paper. This study was carried out during the 8th International Workshop of Group for Aquatic Primary Productivity (GAP) and Batsheva de Rothschild Seminar on Gross and Net Primary Productivity held at the Interuniversity Institute for Marine Sciences, Eilat, Israel, in April 2008. We thank the Batsheva de Rothschild Foundation, Bar Ilan University, and the Moshe Shilo Center for Marine Biogeochemistry for funding. Special thanks to the staff of the Interuniversity Institute and logistic support. Thanks go to T. Rivlin for nutrient analyses, to A. Rivlin for assistance at sea and to the captain and crew of the SeaBell. Particiption in the GAP workshop by E.V.-D. was funded by EUROCEANS, E.V.-D. is recipient of an I3P grant (CSIC-MEC-EU). This work is in partial fulfillment of the requirements for a $\mathrm{PhD}$ thesis for E.B.-Z., who is supported by a Bar Ilan University President's Scholarship.

\section{LITERATURE CITED}

Al-Najjar T, Badran M, Richter C, Meyerhoefer M, Sommer U (2007) Seasonal dynamics of phytoplankton in the Gulf of Aqaba, Red Sea. Hydrobiologia 579:69-83

Al-Qutob M, Häse C, Tilzer MM, Lazar B (2002) Phytoplankton drives nitrite dynamics in the Gulf of Aqaba, Red Sea. Mar Ecol Prog Ser 239:233-239 
Alldredge AL, Passow U, Logan BE (1993) The abundance and significance of a class of large, transparent organic particles in the ocean. Deep-Sea Res I 40:1131-1140

Allgaier M, Riebesell U, Vogt M, Thyrhaug R, Grossart HP (2008) Coupling of heterotrophic bacteria to phytoplankton bloom development at different $\mathrm{pCO}_{2}$ levels: a mesocosm study. Biogeosciences 5:1007-1022

Arrigo KR (2007) Marine manipulations. Nature 450:491-492

Azam F (1998) Microbial control of oceanic carbon flux; the plot thickens. Science 280:694-695

Azam F, Long RA (2001) Sea snow microcosms. Nature 414:495-497

Berman T, Viner-Mozzini Y (2001) Abundance and characteristics of polysaccharide and proteinaceous particles in Lake Kinneret. Aquat Microb Ecol 24:255-264

Berman-Frank I, Rosenberg G, Levitan O, Haramaty L, Mari $\mathrm{X}$ (2007) Coupling between autocatalytic cell death and transparent exopolymeric particle production in the marine cyanobacterium Trichodesmium. Environ Microbiol 9:1415-1422

Bidigare RR, Smith RC, Baker KS, Marra J (1987) Optical production estimates from measurements of spectral irradiance and pigment concentration. Global Biogeochem Cycles 1:171-186

Bidigare RR, Morrow JH, Kiefer DA (1989) Derivative analysis of spectral absorption by photosynthetic pigments in the western Sargasso Sea. J Mar Res 47:323-341

Campbell D, Hurry V, Clarke AK, Gustafsson P, Oquist G (1998) Chlorophyll fluorescence analysis of cyanobacterial photosynthesis and acclimation. Microbiol Mol Biol Rev 62:667-683

Carrias JF, Serre JP, Sime-Ngando T, Amblard C (2002) Distribution, size, and bacterial colonization of pico and nanodetrital organic particles (DOP) in 2 lakes of different trophic status. Limnol Oceanogr 47:1202-1209

Chamberlin S, Marra J (1992) Estimation of photosynthetic rate from measurements of natural fluorescence-analysis of the effects of light and temperature. Deep-Sea Res I 39:1695-1706

> Chamberlin WS, Booth CR, Kiefer DA, Morrow JH, Murphy RC (1990) Evidence for a simple relationship between natural fluorescence, photosynthesis and chlorophyll in the Sea. Deep-Sea Res I 37:951-973

Chin WC, Orellana M, Verdugo P (1998) Spontaneous assembly of marine dissolved organic matter into polymer gels. Nature 391:568-572

Cole JJ, Findlay S, Pace ML (1988) Bacterial production in fresh and saltwater ecosystems: a cross-system overview. Mar Ecol Prog Ser 43:1-10

Corzo A, Morillo JA, Rodriguez S (2000) Production of transparent exopolymer particles (TEP) in cultures of Chaetoceros calcitrans under nitrogen limitation. Aquat Microb Ecol 23:63-72

Edler L (1979) Recommendations for marine biological studies in the Baltic Sea. Phytoplankton and chlorophyll. Baltic Mar Biol 5:5-38

Engel A (2000) The role of transparent exopolymer particles (TEP) in the increase in apparent particle stickiness $(\alpha)$ during the decline of a diatom bloom. J Plankton Res 22:485-497

Engel A, Goldthwait S, Passow U, Alldredge A (2002) Temporal decoupling of carbon and nitrogen dynamics in a mesocosm diatom bloom. Limnol Oceanogr 47: $753-761$

Engel A, Thoms S, Riebesell U, Rochelle N, Zondervan I (2004) Polysaccharide aggregation as a potential sink of marine dissolved organic carbon. Nature 428:929-932
Genin A, Lazar B, Brenner S (1995) Vertical mixing and coral death in the Red Sea following the eruption of mountPinatubo. Nature 377:507-510

Grossart HP, Ploug H (2001) Microbial degradation of organic carbon and nitrogen on diatom aggregates. Limnol Oceanogr 46:267-277

> Grossart HP, Simon M (2002) Bacterioplankton dynamics in the Gulf of Aqaba and the northern Red Sea in early spring. Mar Ecol Prog Ser 239:263-276

Grossart HP, Simon M, Logan BE (1997) Formation of macroscopic organic aggregates (lake snow) in a large lake: The significance of transparent exopolymer particles, phytoplankton, and zooplankton. Limnol Oceanogr 42: 1651-1659

> Herndl GJ, Agogué H, Baltar F, Reinthaler T, Sintes E, Varela MM (2008) Regulation of aquatic microbial processes: the 'microbial loop' of the sunlit surface waters and the dark ocean dissected. Aquat Microb Ecol 53:59-68

Hong Y, Smith WO, White AM (1997) Studies on transparent exopolymer particles (TEP) produced in the Ross Sea (Antarctica) by Phaeocystis antarctica (Prymnesiophyceae). J Phycol 33:368-376

Iluz D (1997) The light field, phytoplankton pigmentation and productivity in the Gulf of Eilat. PhD thesis, Bar-Ilan University, Ramat-Gan

Iluz D, Dishon G, Capuzzo E, Meeder E and others (2009) Short-term variability in primary productivity during a wind-driven diatom bloom in the Gulf of Eilat (Aqaba). Aquat Microb Ecol 56:205-215

Kepkay P (2000) Colloids and the ocean carbon cycle. In: Wangersky P (ed) The handbook of environmental chemistry, Vol 5. Springer Verlag, Berlin, p 35-56

Kiefer DA, Chamberlin WS, Booth CR (1989) Natural fluorescence of chlorophyll a: relationship to photosynthesis and chlorophyll concentration in the western South Pacific gyre. Limnol Oceanogr 34:868-881

Kirchman D, Knees E, Hodson R (1985) Leucine incorporation and its potential as a measure of protein-synthesis by bacteria in natural aquatic systems. Appl Environ Microbiol 49:599-607

Labiosa RG, Arrigo KR (2003) The interplay between upwelling and deep convective mixing in determining the Seasonal phytoplankton dynamics in the Gulf of Aqaba: Evidence from SeaWiFS and Modis. Limnol Oceanogr 48: 2355-2368

Lindell D, Post AF (1995) Ultraphytoplankton succession is triggered by deep winter mixing in the Gulf of Aqaba (Eilat), Red-Sea. Limnol Oceanogr 40:1130-1141

Logan BE, Alldredge AL (1989) Potential for increased nutrient uptake by flocculating diatoms. Mar Biol 101:443-450

Mari X (1999) Carbon content and C:N ratio of transparent exopolymeric particles (TEP) produced by bubbling exudates of diatoms. Mar Ecol Prog Ser 183:59-71

Mari X, Burd A (1998) Seasonal size spectra of transparent exopolymeric particles (TEP) in a coastal sea and comparison with those predicted using coagulation theory. Mar Ecol Prog Ser 163:63-76

Mari X, Kiørboe T (1996) Abundance, size distribution and bacterial colonization of transparent exopolymeric particles (TEP) during spring in the Kattegat. J Plankton Res 18:969-986

Mari X, Rassoulzadegan F, Brussaard CPD (2004) Role of TEP in the microbial food web structure. II. Influence on the ciliate community structure. Mar Ecol Prog Ser 279:23-32

Menden-Deuer S, Lessard EJ (2000) Carbon to volume relationship for dinoflagellates, diatoms and other protest plankton. Limnol Oceanogr 45:569-579 
Mopper K, Schultz C, Chevolot L, Germain C, Revuelta R, Dawson R (1992) Determination of sugars in unconcentrated seawater and other natural waters by liquid chromotography and pulsed amperometric detection. Environ Sci Technol 26:133-138

Passow U (2000) Formation of transparent exopolymer particles, TEP, from dissolved precursor material. Mar Ecol Prog Ser 192:1-11

Passow U (2002a) Transparent exopolymer particles (TEP) in aquatic environments. Prog Oceanogr 55:287-333

Passow U (2002b) Production of transparent exopolymer particles (TEP) by phyto- and bacterioplankton. Mar Ecol Prog Ser 236:1-12

Passow U, Alldredge AL (1994) Distribution, size, and bacterial colonization of transparent exopolymer particles (TEP) in the ocean. Mar Ecol Prog Ser 113:185-198

Passow U, Alldredge AL (1995) A dye-binding assay for the spectrophotometric measurement of transparent exopolymer particles (TEP). Limnol Oceanogr 40: 1326-1335

Passow U, Alldredge AL, Logan BE (1994) The role of particulate carbohydrate exudates in the flocculation of diatom blooms. Deep-Sea Res I 41:335-357

Passow U, Engel A, Ploug H (2003) The role of aggregation for the dissolution of diatom frustules. FEMS Microbiol Ecol 46:247-255

Reiss Z, Hottinger L (1984) The Gulf of Aqaba: Ecological micropaleontology. Springer-Verlag, Berlin

Schuster S, Herndl GJ (1995) Formation and significance of transparent exopolymeric particles in the northern Adriatic Sea. Mar Ecol Prog Ser 124:227-236

Simon M, Azam F (1989) Protein content and protein synthe-

Editorial responsibility: Hugh MacIntyre,

Dauphin Island, Alabama, USA sis rates of planktonic marine bacteria. Mar Ecol Prog Ser 51:201-212

Simon M, Alldredge AL, Azam F (1990) Bacterial carbon dynamics on marine snow. Mar Ecol Prog Ser 65:205-211

Smetacek VS (1985) Role of sinking in diatom life-history cycles-ecological, evolutionary and geological significance. Mar Biol 84:239-251

Smith S, Azam F (1993) A simple economical method for measuring bacterial protein synthesis rates using ${ }^{3} \mathrm{H}$ leucine. Mar Microb Food Webs 6:107-114

> Stambler N (2006) Light and picophytoplankton in the Gulf of Eilat (Aqaba). J Geophys Res Oceans 111, C11009, doi: 10.1029/2005JC003373

> Stoderegger KE, Herndl GJ (1999) Production of exopolymer particles by marine bacterioplankton under contrasting turbulence conditions. Mar Ecol Prog Ser 189:9-16

Thornton DCO (2002) Diatom aggregation in the sea: mechanisms and ecological implications. Eur J Phycol 37: 149-161

Utermöhl H (1958) Zur Vervollkommnung der quantitativen Phytoplankton-Methodik. Mitt Int Verein Theor Angew Limnol 9:1-38

- Vázquez-Domínguez E, Duarte CM, Agustí S, Jürgens K, Vaqué D, Gasol JM (2008) Microbial plankton across the Central Atlantic Ocean in spring and fall 1995. Prog Oceanogr 79:83-94

Worm J, Sondergaard M (1998) Alcian blue-stained particles in a eutrophic lake. J Plankton Res 20:179-186

Zhou J, Mopper K, Passow U (1998) The role of surface-active carbohydrates in the formation of transparent exopolymer particles by bubble adsorption of seawater. Limnol Oceanogr 43:1860-1871

Submitted: December 1, 2008; Accepted: May 6, 2009 Proofs received from author(s): July 23, 2009 